\title{
5. \\ SPLITSKI „KROČEANCI“: JEDAN \\ POGLED U KULTURU GRADA SPLITA \\ IZMEĐU DVA SVJETSKA RATA
}

\section{Tonko Maroević}

UDK: 316.7(497.5 Split)“192/193“

Izlaganje na skupu

Sažetak: U Splitu su 1920-ih i 1930-ih godina djelovali mnogi pisci, slikari i povjesničari, formirani pretežno u Italiji, kao i dobri poznavatelji talijanskog jezika i kreativnih nastojanja na Apeninskom poluotoku. Bili su stoga gotovo idealni prijenosnici talijanske kulture u hrvatski ambijent. U vremenu intenzivne fašizacije talijanskog društva i kulture Benedetto Croce bio je mislilac i kulturni stvaralac koji je, svojim afirmiranjem izražajnog aspekta umjetnosti, autonomije stvaralaštva te izražajnog liberalizma i antifašizma, bio naročito utjecajan među splitskim umjetnicima građanskih orijentacija nepovezanih sa „socijalnim“ pokretima, poput „krležijanaca“. Cinili su krug splitskih „kročeanaca“. Među njima najviše pozornosti zaslužuje Bogdan Radica, i kao književni kritičar i kao Croceov sugovornik. Potom se ističu Albert Haler, Stipan Banović, Tin Ujević, Vinko Vitezica, krug mlađih suradnika splitskog časopisa Korablja Ćire Čičin Šaina, poput Ante Cettinea i Vladimira Rismonda te Vladan Desnica, koji je kao „kročeanac“ izrastao i iz obiteljske tradicije. Desnica 1938. prevodi i objavljuje u Splitu znalački izabrane Croceove Eseje iz estetike. Radi to u vrijeme kada se odlučio posvetiti književnom pozivu i kada je i počeo pisati neke od svojih najboljih radova.

Ključne riječi: Benedetto Croce, Split, 1918. - 1941., Bogdan Radica, Vladimir Rismondo, Vladan Desnica

osvećujući se temi splitskih „kročeanaca“, prihvatio sam izazov ne sasvim lake problematike. ${ }^{1}$ Naime, jasno mi je bilo da su organizatori Desničinih susreta - znajući koliko je naš veliki pisac u svojem splitskom razdoblju bio obuzet djelom značajnoga talijanskog filozofa - traži od mene da pokušam ocrtati kulturni okvir toga grada i odgovarajući idejno-teorijski kontekst toga vremena. Pretpostavka je bila da Vladan Desnica nije bio potpuno osamljen u svojim interesima za djelo autora koji je - u dominantnom fašističkom okružju - simbolizirao liberalni duh susjedne nam zemlje i svojim estetičkim i povjesničarskim tekstovima široko utjecao na noviju književnost u mnogim europskim zemljama,

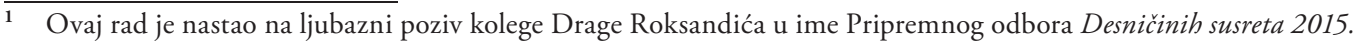


ali i na politički život. Tu je pretpostavku jačala činjenica da iz Splita potječu i da su u Splitu dvadesetih i tridesetih godina prošloga stoljeća intenzivno djelovali mnogi pisci, slikari i povjesničari formirani pretežno u Italiji, dakle dobri poznavaoci jezika i kreativnih nastojanja na Apeninskom poluotoku, stoga i gotovo idealni prenosnici talijanske kulture u hrvatski ambijent.

Moje prihvaćanje tog izazova određeno je s nekoliko različitih razloga. Potječem iz Splita i poznavao sam mnoge kreativne ljude i znao publikacije vezane za talijanističke teme. Zainteresiran sam za formativne impulse i tekovine Vladana Desnice. Sretnim stjecajem okolnosti odavno sam bio nabavio Eseje iz estetike Benedetta Crocea, što ih je Desnica preveo i objavio u Splitu 1938. godine, a još je zanimljiviji slučaj da sam u splitskim antikvarijatima tijekom godina kupio čak četiri knjige Benedetta Crocea na talijanskom jeziku, u izvornom izdanju Laterza iz Barija. Već taj podatak da je Croceovo djelo čitano u originalu, nabavljano u više navrata (jer su edicije iz različitih godišta), govori o određenom utjecaju i odjeku u splitskoj kulturnoj sredini te svjedoči o mogućnosti postojanja - makar uskoga - kruga Croceovih poštovalaca, proučavalaca, pratilaca, da ne kažemo: sljedbenika.

Ali od te zanimljive premise pa do tvrdnje o nekoj čvrstoj jezgri „kročeanaca“ u splitskoj sredini dalek je put. Izvjesno je da zaljubljenici u filozofa, estetičara ne mogu biti tako brojni kao, primjerice, fanovi nekog pjesnika, prozaika i dramatičara. Recimo: „krležijanci“ su jamačno između dva svjetska rata bili vrlo relevantna idejna i kulturna skupina razmjerno homogene orijentacije, ali baš ni krležijanaca nije bilo u Splitu odveć (tomu ćemo se, gotovo nehotice, navratiti na samom kraju ovoga članka). Dakle, „kročeanci“ su mogli biti tek uska elita, vezani za tanki građanski sloj srednje klase, a politički pritom mnogo bliži centru negoli (komunističkoj) ljevici.

Možda bismo mogli započeti s Bogdanom Radicom, rođenim Splićaninom i splitskim đakom, koji je među prvima kod nas pisao o Croceu, a tokom života s njime se i upoznao i s njime razgovarao (taj je razgovor čak tiskan u pariškom listu Le Monde). Uostalom, primjerak Croceove Estetike iz 1917. godine što sam ga kupio u Splitu, nosio je upravo njegov potpis, bio je njegovo vlasništvo. Premda su Radicu ispočetka više zanimali pisci poput Papinija, Prezzolinija, Palazzeschija i Cardarellija, na Crocea se po prvi put osvrnuo 1925. godine u jednom kumulativnom članku, ${ }^{2}$ a potom 1929 . godine $\mathrm{u}$ sličnom okviru, ${ }^{3}$ da bi 1936. godine slavio piščevu sedamdesetgodišnjicu (zajedno s Romainom Rollandom) pod majestetičnim naslovom „Dva svedoka današnje Evrope“. ${ }^{4}$ Naposljetku, u knjizi Agonija Evrope (1940.) Radica posvećuje Croceu vrlo afirmativan uvodni esej i svjedočanstva o susretima. ${ }^{5}$ Mjerodavni poznavalac piščeva opusa i društvene zbilje, daje više nego prikladnu karakterizaciju: „Samoća u kojoj je Crocea gurnula politička stvarnost mistificiranog

2 Bogdan Radica, „Anekdote o talijanskim piscima“, Nova Evropa, 1925., knj. 12, br. 9, 284.

3 Istı, „Bilješke iz talijanske književnosti“, Hrvatska revija, 2/1929., br. 7, 445-448; „Dvije historije B. Crocea“, $H r$ vatska revija, 2/1929., br. 7, 445-447.

4 Isti, „Dva svedoka današnje Evrope“, Nova Evropa, 1936., knj. 29, br. 3, 91-96.

5 Isti, Agonija Evrope. Razgovori i susreti, Beograd 1940. 
idealizma nacionalfašističke države vratila ga je Evropi velike tradicije individualizma i aristokratskog liberalizma.“ Dodaje da „u poniženoj i intelektualno sasušenoj sredini svoje domovine Croce rješava svoje intelektualno i moralno nezadovoljstvo usavršavanjem i popunjavanjem svoje misli“. 6

$\mathrm{Na}$ Crocea se Radica navraća i u svojim memoarskim zapisima Živjeti nedoživjeti, gdje se prisjeća kako je u pariškoj verziji razgovora s filozofom iznio podatak o pustošenju njegove knjižnice sa strane mladih fašista, što ga je potom morao u sljedećim objavama ispustiti (nakon piščeva demanta, prouzročena strahom od daljnjih negativnih posljedica). ${ }^{7}$ Ali možemo zaključiti kako je Croce za Radicu postao svojevrsnim uzorom etičkog ponašanja i intelektualnog poštenja, svjetionikom nadnacionalnih europskih perspektiva.

Svakako najveći zagovornik Croceove estetike i teorije umjetnosti u hrvatskoj sredini bio je Albert Haler, rođeni Vrgorčanin, dubrovački gimnazijalac i bečki doktorant. Pod utjecajem kritičke metode i specifične aksiološke revizije talijanske književnosti napuljskog filozofa, nastojao je i u našoj sredini provesti mijenu ustaljenih književnih kanona, u korist čiste poezije i bistre intuicije, a na uštrb pedagoškog funkcionalizma i rodoljubne patetike. Svoje je načelne stavove, na tragu Crocea, izložio u djelu Doživljaj ljepote (1943.), a kritičko polemičke studije usmjerio je oštrom prevrednovanju Gundulića i Preradovića, dotada smatranih uzornim pjesnicima. ${ }^{8}$ Premda nije djelovao u splitskom krugu, njegovo je pisanje izazvalo odlučne reakcije upravo splitskih autora.

Stipan Banović replicira Haleru člankom „Obaranje dvojice najvećih hrvatskih pjesnika“, gdje ne štedi autora i zbog suradnje u Srpskom književnom glasniku i objavljivanja knjige u Beogradu, nalazeći u tom napadu i kompenzaciju zbog svoje nedostatne argumentacije. Zanimljivo je međutim za našu temu kako Banović ulazi u meritum Halerova kročeanizma pa navodimo oduži citat:

Kao što je i Branislav Miljković napomenuo: dr. A. Haler je sljedbenik talijanskoga suvremenog filozofa Benedetta Crocea, o kome je Haler napisao prikaz u „Srpskom književnom glasniku“ (1929. br. 123-132., 194-201.). Haler kod naših pjesnika primjenjuje nauku Croce-ovu: da je svaki estetski akt prvi stepen doživljavanja realnosti, turajući pod tu tvrdnju „proizvoljno" najljepše pjesme naših prvih pjesnika. Međutim su i u samoj Italiji veoma žestoko napali Croce-ovo estetičko načelo: da je umjetnička tvorevina fizički akt proglasivši ga posve nerealnim i fantastičnim. Fraza „proživljenost“, koje se štovatelji Croceovi drže kao pijan plota, ne donosi u estetici ništa posve novo, jer je od pamtivijeka postojalo isto shvaćanje u riječima: istinitost, iskrenost, naravno, uvjerljivo, psihološki itd. Prema „proživljenosti“ Croce-ovoj je na pr. i njemački estetski teoretik Volkelt u svojoj knjizi „System der Aesthetik“" postavio načelo „proosjećanja“. ${ }^{10}$

6 Istı, „Benedeto Kroče. O prekretnici evropske civilizacije“, Agonija Evrope, 144.

7 Isti, Živjeti nedoživjeti, knj. 1: Uspomene hrvatskog intelektualca kroz moralnu i ideološku krizu Zapada, München Barcelona 1982., 290-291.

8 Albert Haler, Doživljaj ljepote, Zagreb 1943.

9 Stipan Banović, „Obaranje dvojice najvećih hrvatskih pjesnika“, Hrvatsko kolo, 1930., knj. 11, 205-245.

10 Isto, 242-243. 
Istim se povodom oglasio i kontroverzni splitski pisac, polihistor, polemičar i političar Kerubin Šegvić u prilogu naslovljenom „Je li Petar Preradović bio pjesnik “. ${ }^{11}$ Pozivajući se na iskustvo vlastita čitanja i težinu vlastitih doživljaja, Šegvić dakako brani glasovite Preradovićeve pjesme i stihove (kao digresija, dopušta negativni sud o Preradovićevim njemačkim skladanjima, premda su ona ništa manje spiritualna i slikovita). Ono što nas posebno mora zanimati, Šegvić ne samo da poznaje Croceovu Estetiku i iz originala je citira, nego se poziva na Crocea kako bi oborio neke od Halerovih stavova, što možemo vidjeti iz ovoga ulomka:

Premda može biti poezije i ondje, gdje nema posebne ritmičke forme, posebne tehnike (poezija u prozi), ipak je vanjska forma, tehnika bitni faktor poezije za postignuće efekata. Najmoderniji estetičar Benedetto Croce piše: „Pjesniku, slikaru, kojemu fali forma, fali mu sve, nema ništa, jer nema sebe. Pjesnička sadržina je u svačijem srcu, samo izraz i oblik čini nekoga pjesnikom (Estetica, pg. 28.). Ne može se odijeliti, veli isti pisac (pg. 29.) intelekat od osjećaja (l'inteletto è anche sentimento), zato se ne može poricati poetičnost u Preradovićevim pjesmama stoga što je u njima jak intelektualistički dio. ${ }^{12}$

Jedan drugi rođeni Vrgorčanin, veliki Tin Ujević, pokazat će se također vrlo dobrim poznavaocem Croceove estetike, naravno ne i pobožnim sljedbenikom poput Halera već, naprotiv, učestalim kritičkim suputnikom i pretežno ironičnim komentatorom njegovih ideja. U Ujevićevim sabranim djelima nema proznoga sveska u kojemu se ne bi referiralo i na poneki Croceov stav ili tezu, a veliki dio tekstova s referencama na napuljskog filozofa objavljivan je upravo u splitskim dnevnim novinama koncem trećega desetljeća prošloga stoljeća. Premda tada još nije živio u Splitu, gdje će se doseliti tek 1937. godine (nego u Sarajevu) na taj se način Ujević također odužuje sredini u kojoj se gimnazijski školovao is kojom je trajno održavao emotivne i intelektualne veze.

U članku „Sumrak poezije“ (1929.) Tin Ujević odmah uspostavlja nužnu rezerviranost naspram teoretičara:

Koji bi estetičar, možda Benedetto Croce, mogao sebi da laska da je, jednom formulom, objasnio sva pjesnička djela, od Homera pa do Verlainea i Tollera. (...) Ja protivno od Benedetta Crocea, koji je kazao da je umjetnost ,auroralni oblik saznanja“, dakle put početnika za otkrivanje istine, samostalno sudim da je umjetnost baš krepuskolarni, završni oblik saznanja. ${ }^{13}$

Niz Ujevićevih članaka u Jadranskoj pošti tokom 1930. godine pružio je povode za brojne eruditske opaske i kulturalne teme, gdje se nije moglo mimoići Croceovo ime i njegovo mišljenje. Tekst posvećen velikom bengalskom pjesniku pod naslovom „Tagor“ prilika je za pjesnikov obračun s dogmatizmom i simplicizmom klasifikacija: „Estetika Benedetta Crocea, kao i filozofija Hypolitea Tainea, napisane su više na temelju klasicizma, pa previđaju kao po sistemu cijeli red djela drugog smjera i duha. ${ }^{\text {“14 }} \mathrm{U}$ tekstu naslovljenom „Experto Ro-

\footnotetext{
11 Kerubin ŠEgvić, „Je li Petar Preradović bio pjesnik“, Hrvatska revija, 5/1932., br. 1, 57-66.

12 Isto, 59.

13 Tin Ujević, „Sumrak poezije“, Novo doba (Split), br. 312, 24. 12. 1929., 18.

14 Isti, „Tagor. Ovjenčani pjesnik Indije“, Jadranska pošta (Split), br. 106, 8. 5. 1930., 6-7.
} 
berto“ izražava se još razornije: „Estetika Benedetta Crocea svakako se ukazuje kao 'gageure', često puta igra riječi i optičkih opsjena putem istih formula za stvari veoma različne. ${ }^{\text {"15 }}$ Pišući o Franji Petriću, renesansnom filozofu Patritiusu, podrijetlom iz naših strana, sa zadovoljstvom spominje da ga i Croce uzima u obzir ${ }^{16}$ dok članak „Atenski upečatak g. Bogdana Radice" referira o novinarskoj agilnosti splitskoga kolege, koji je upoznao i Crocea, a „s Papinijem, Unamunom, Croceom ima veliku prepisku“. ${ }^{17}$ Mimo splitskih adresa objavljivanja spomenut ćemo još glasoviti Ujevićev esej „Trnokop u Silvijevoj bašti“ tiskan u sarajevskom Pregledu, gdje stoji relevantna primjedba: „Na Kranjčevića nije uputno ni primjenjivati mjerila Croceove estetike." ${ }^{\text {"18 }}$

Rođeni Trogiranin, a splitski gimnazijalac, klasičar, Vinko Vitezica stekao je neporecivih zasluga u prezentaciji i populariziranju Croceova opusa prijevodom kapitalne knjige Estetika, koje je prvo izdanje popratio i studioznim predgovorom (Beograd, 1935.). Drugo, revidirano izdanje istoga prijevoda izašlo je u Zagrebu 1960. Iako nije imao pravih dodira sa splitskim predratnim književnim zbivanjima, recepcija po njemu priređena Croceova izdanja bila je široka u čitavom južnoslavenskom prostoru i nije mogla ostati bez odjeka i u Splitu. ${ }^{19}$

Osim navođenih značajnih novina što su izlazile u Splitu tokom dvadesetih i tridesetih godina, a bile su važne i zbog bogate feljtonistike i literarnih priloga (posebno u svečanim, blagdanskim brojevima Novoga doba), u istom se razdoblju javilo i par pokušaja izdavanja književnih i kulturnih časopisa. Najraniji je od njih bio Renesansa, a prvi i jedini broj pojavio se u studenome 1921. godine. Vrlo solidne razine i naglašene estetske orijentacije, $s$ osobitim pogledima na drugu stranu Jadrana (na Dantea, Papinija, Carduccija itd.), taj list nije u svoj obzor uklopio i Croceovu pojavu. Uredio ga je Ivo Dellale, splitski kanonik i pisac odnjegovana stila, a osigurao je suradnju pretežno katoličkoga kruga (Antun Petravić, Jakov Kostović, Ladislav Glavina, Ante Dellale), kojemu Croceov liberalizam nije mogao biti po volji, no dvojim da je tako informiranim čitateljima i znalcima talijanske književnosti kao što su bili Dellale i Petravić Croceovo ime i djelo ostalo sasvim nepoznato. Slično bih se usudio tvrditi i za Vinka Lozovinu, autora povijesti starije talijanske književnosti i monografa Machiavellijeva, a to se pogotovo odnosi na pjesnika i kritičara Tona Smerdela, također splitskog gimnazijalca i odličnog pratitelja estetike i poetike s druge obale Jadrana.

Izlazak časopisa Korablja obećavao je povezivanje gotovo svih raspoloživih kulturnih i književnih snaga u regiji, ali je sve stalo na dva broja, dva sveska u 1929. godini. To je bio i pokušaj međugeneracijskog dijaloga i nastojanje oko okupljanja iseljenih i u Splitu (i Dalmaciji) djelatnih pisaca. Pod uredništvom Ćire Čičin Šajina okupili su se i predstavnici starije generacije (od Cara Emina i Katalinića Jeretova do Tresića Pavičića i Luje Vojnovi-

\footnotetext{
15 Isti, „Experto Roberto (Prelistavajući Thomasa Manna)“, Jadranska pošta (Split), br. 129, 5. 7. 1930., 6-7; br. 130, 6. 7. 1930., 6-7; br. 131, 7. 7. 1930., 6-7.

16 Isti, „Poslije četiri stoljeća. Klišanin Patritius rođen 1529.“, Jadranska pošta (Split), br. 36, 13. 2. $1930 ., 2$.

17 Isti, „Atenski upečatak g. Bogdana Radice“, Jadranska pošta (Split), br. 186, 12. 8. 1930., 6-7.

18 Isti, „Trnokop u Silvijevoj bašti“, Pregled, 7/1933., knj. 9, sv. 119, 631 - 639.

19 Usp. Benedeto Kroče, Estetika kao nauka o izrazu i opšta lingvistika, Beograd 1935. i Benedetto Croce, Estetika kao nauka o izrazu i opća lingvistika, Zagreb 1960.
} 
ća) i zagovornici tada aktualnijih stremljenja (od Bartulovića i Cettinea do Anđelinovića i Rismonda, Verke Škurle Ilijić i Pere Ljubića). Više je nego izvjesno da naraštaj formiran početkom stoljeća (Tresić, Sabić, Ilijić, Katalinić) nije bio osjetio potrebu reagiranja na onda upravo stasalu Croceovu estetičku misao, ali generacija tada mlađih autora mogla je (i čak morala) nekako se odrediti prema Croceu. U njihovo ime, takoreći, u prvom broju Korablje oglasio se tada dvadesetpetogodišnji Radica svojim prikazom Halerove knjige Gundulićev Osman s estetskog gledišta. Za razliku od spominjanih Banovića i Šegvića, on je izrazito afirmativan u procjeni Halerove estetske „diverzije“, to jest odlučnoga prevrednovanja Gundulićeva spjeva, videći u tomu ,jedan nov tip književne kritike“, odnosno ostvarenje koje bi „u pljesnivi magazin naše literarne historije unijelo malo više poezije, malo više daha i malo više života“. ${ }^{20}$ Naravno, Radica je duboko svjestan Halerova oslanjanja na Crocea:

Iznijevši Gundulićeva „Osmana“ „s estetskog gledišta“, a na jednoj osnovi koja je otkrivena od Crocea, a koja definira „pojam umjetnosti, kao liriku ili lirsku intuiciju“, g. Haler je u prvom redu imao smionosti da se sukobi sa skoro svim dosadašnjim tumačenjima Gundulićeva djela... ${ }^{21}$

Pritom Radica izravno navodi neka mjesta iz Croceovih knjiga La poesia di Dante (1921.) i Ariosto, Shakespeare e Corneille (1920.). ${ }^{22}$

Radičin esej „Nostalgije za redom“ (iz spomenutog broja Korablje) vrlo je ambiciozan pokušaj fiksiranja duhovne klime epohe i dijagnoze nekih karakterističnih fenomena glavnih središta Europe (retour à l'ordre). ${ }^{23} \mathrm{U}$ taksativnom pregledu dominantnih imena - uglavnom romanskih ishodišta - kojima se naslućuje mogućnost izlaska iz krize, među prvima je, opet, naravno, i Croce:

Pored polomljenih pozitivističkih trijemova i palača osjeća se još uvijek, kako i u liniji jednog Bergsona ili jednog Crocea, mogu da se nastave tapkanja kroz mrak. A po Leonardovim tragovima još se i danas u lirskom sabranju susreće aristokratski i suptilni mozak jednog Valérya. ${ }^{24}$

Dolazimo do Desničine inicijative pokretanja Magazina Sjeverne Dalmacije (1934. i 1935.), u kojemu, dakako, nema izravnih naznaka Croceova utjecaja, ali u kojemu - uz glavnog urednika i bliske srodnike - surađuju Vladimir Rismondo i Ćiro Čičin Šajin (znani nam iz Korablje) te slikar Vjekoslav Parać, koji mogu tvoriti i stanoviti prijateljski krug. Znano nam je da se Vladan u splitskom razdoblju još druži i s kiparom Dujmom Penićem i kompozitorom Ivom Paraćem, a posjećujući izložbe svakako prati i rat Emanuela Vidovića, Antuna Zuppe, Jerolima Miše i Marina Tartaglije (sve talijanskih đaka). Pridodajmo još potencijalne vršnjačke odnose, primjerice s Olinkom Delorkom (kojemu Desnica

\footnotetext{
20 Bogdan Radica, „Albert Haler: ‘Gundulićev Osman' - (S estetskog gledišta, Izd. Gece Kona. - Beograd, 1929.)“, Korablja, 1/1929., br. 1, 51.

21 Isto, 50.

22 Moram napomenuti da to nisu svesci što sam ih nabavio u splitskim antikvarijatima, što znači da je Radica raspolagao većim izborom i bio duboko involviran u Croceov opus.

23 Bogdan Radica, „Nostalgije za redom“, Korablja, 1/1929., br. 1, 37-41.

24 Isto, 38.
} 


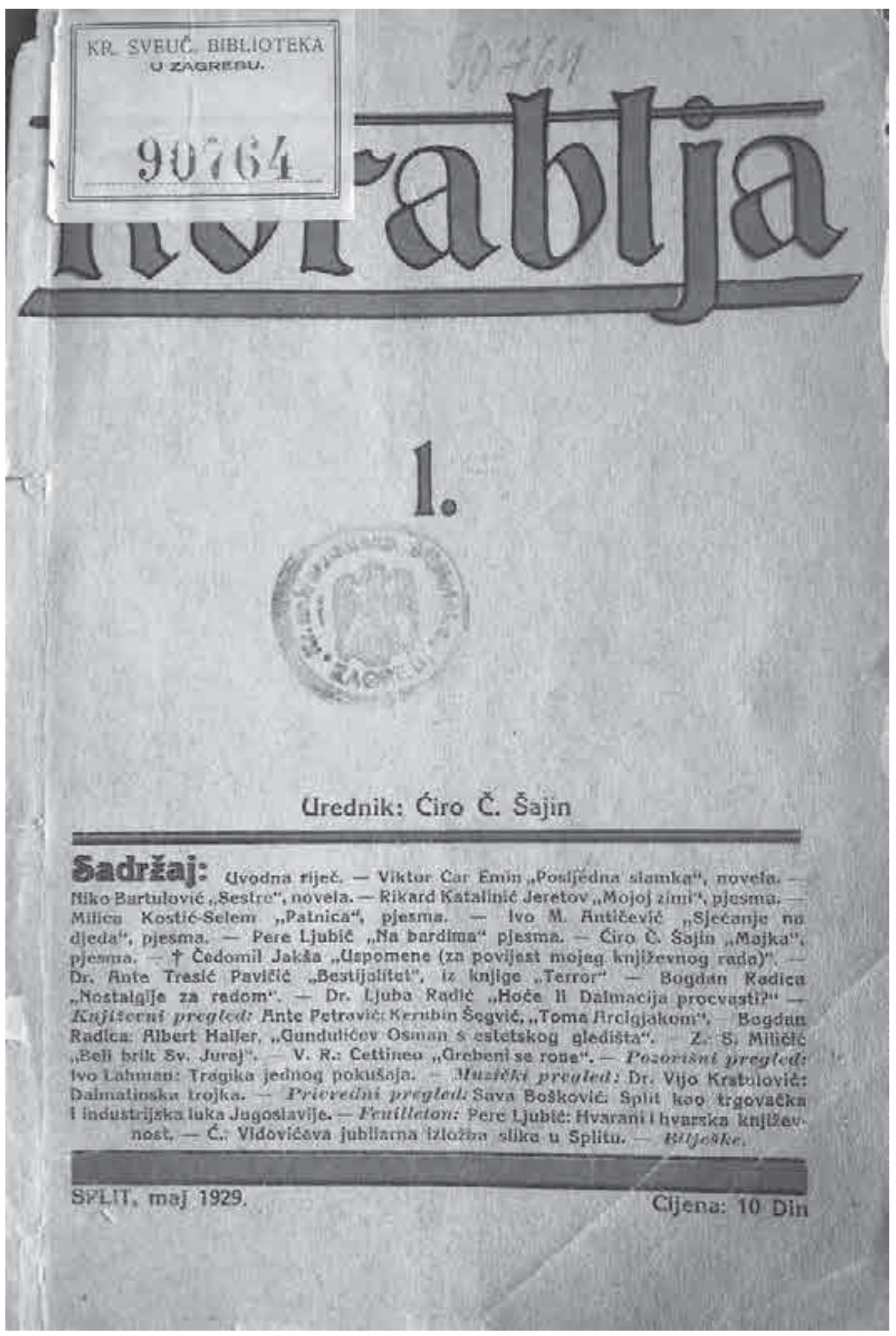


šalje na uvid i objavljivanje svoje pjesme), možda is Vojmilom Rabadanom, pa s Dragom Ivaniševićem ili, pogotovo, s nešto starijim Antom Cettineom, mogli bismo idealno zaokružiti mali cenakulum (valjda kompetentnih) razgovornika o Croceu. A jedini pouzdani „kročeanac“, među svima spomenutima, svakako je Vladimir Rismondo, Desničin najbliži prijatelj i pratitelj, pisac izričite mediteranske orijentacije i estetičke inspiracije. Rismondo makar se intenzivno bavio i Croceovim antipodom Pirandellom - svakako je zainteresiran i za Crocea. (Zanima ga, uostalom, i kao povjesničar, čime se i sam profesionalno bavi.)

„Kročeanstvo“ Vladana Desnice na neki je način i nasljedno. Boško Desnica, „s piščevim ovlašćenjem“, prevodi još 1912. važan Croceov esej „O jednom karakteru novije talijanske književnosti“ i objavljuje ga u Srpskom književnom glasniku. ${ }^{25}$ Doista, obiteljska tradicija visoke pismenosti i pristranoga zanimanja za talijanske autore u mnogome je obilježila rad našega pisca, ali on je toj diletantsko-amaterskoj zaokupljenosti dao dodatnu visoko profesionalnu i jako kreativnu dimenziju.

Vrhunac Desničina bavljenja Croceom u splitskom razdoblju predstavlja - također obilježeno vrijednom naznakom „s autorskim ovlaštenjem“ - prevođenje i izdavanje knjige Eseji iz estetike. ${ }^{26} \mathrm{Na}$ šezdesetak stranica sačinjen je vrlo dobar izbor tekstova, svojevrsna sinteza dominantnih estetičkih ideja i problema. Prvi naslov „Čista intuicija i lirski karakter umjetnosti“ predstavlja Croceovo predavanje iz 1908. godine u Heidelbergu, gdje je na filozofskom kongresu izložio temeljne postavke svoje upravo zasnovane cjelovite teorije (s pregledom povijesnih slojeva i temelja). Drugi esej „Umjetnost kao stvaranje i stvaranje kao činjenje" nudi uvid u osnovne pojmove filozofova idealističkog shvaćanja, a od samoga naslova ukazuje na problematiku prevođenja kao kovanja odgovarajuće terminologije u našemu jeziku. Treći tekst ima možda najveću empirijsku podlogu i mogućnost primjene: „Vanestetski pojam lijepoga i njegova upotreba u kritici“. Ali, po mojem mišljenju, najveću programatsku težinu ima objavljivanje četvrtoga eseja, nazvanoga „Književnost kao ‘izraz društva'“.

Riječ je o sasvim kratkom tekstu, svojevrsnoj glosi ili eruditskoj bilješci, u kojoj veliki znalac povijesnih tokova i sudbine ideja, takoreći usputno, demantira ili ironično sagledava napore nekih tada aktualnih ili pomodnih mislilaca da literaturu sagledaju u najstrožoj sprezi s društvenim kretanjima. Na svega četiri stranice Croce je demonstrirao rijetku polemičku vještinu, u kojoj precizna faktografija ruši nesuvisle konstrukcije i neopravdane pretenzije. Implicitna poruga se očituje već iz prve rečenice: „Nije poznato, ili bar obično ne pada na um, da formulu 'književnost je izraz društva' koja je tako revolucionarno djelovala u kritici, dugujemo dvama velikim reakcionerima, vikontu de Bonald i baronu de

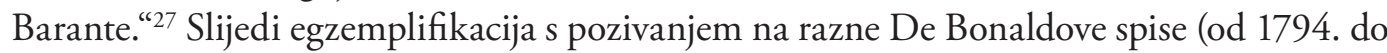
1808.), u kojima on tumači književnost kao izraz društva, odnosno vidi je kao postupni napredak od naivnosti i domaće prisnosti do veće otmjenosti i javne prihvaćenosti. De Baran-

$\overline{25}$ Boško DesnicA, „O jednom karakteru novije talijanske književnosti“, Srpski književni glasnik, 1912., knj. 29, br. 4, 291-300; br. 5, 371-376.

26 Knjiga je izašla u Nakladi Kadmos, u Splitu 1938. godine. Bila je to piščeva vlastita naklada, a ova Croceova knjiga jedina je koju je Kadmos objavio.

27 Benedetto Croce, „Književnost kao 'izraz društva'“, Eseji iz estetike, Split 1938., 59. 
te pak ukazuje kako je nemoguće uvidjeti društvene promjene ukoliko književnost ne pokaže odgovarajuće zbivanje. Kod tih starijih autora formula se mogla shvatiti i restriktivno, pa i obratno. Naime, da književnost nije znanost ili filozofija o društvu, nego samo izraz, pa je time i nezavisna i autonomna u odnosu na znanstvene discipline. Slijedi, međutim, Croceova izričita polemička oštrica:

Moderni sociolozi, koji su (barem u pitanjima estetske teorije) tim staromodniji čim su moderniji, daju formuli jedno značenje koje je sasvim daleko ne samo od njenoga prvotnog značenja, nego i daleko od istine. Oni kažu: književnost je izraz društva; ona dakle mora da promiče korist i da zadovoljava potrebe društva. I tako će onaj kome leži na srcu radničko pitanje zahtijevati socijalističku književnost, a onaj ko zauzima

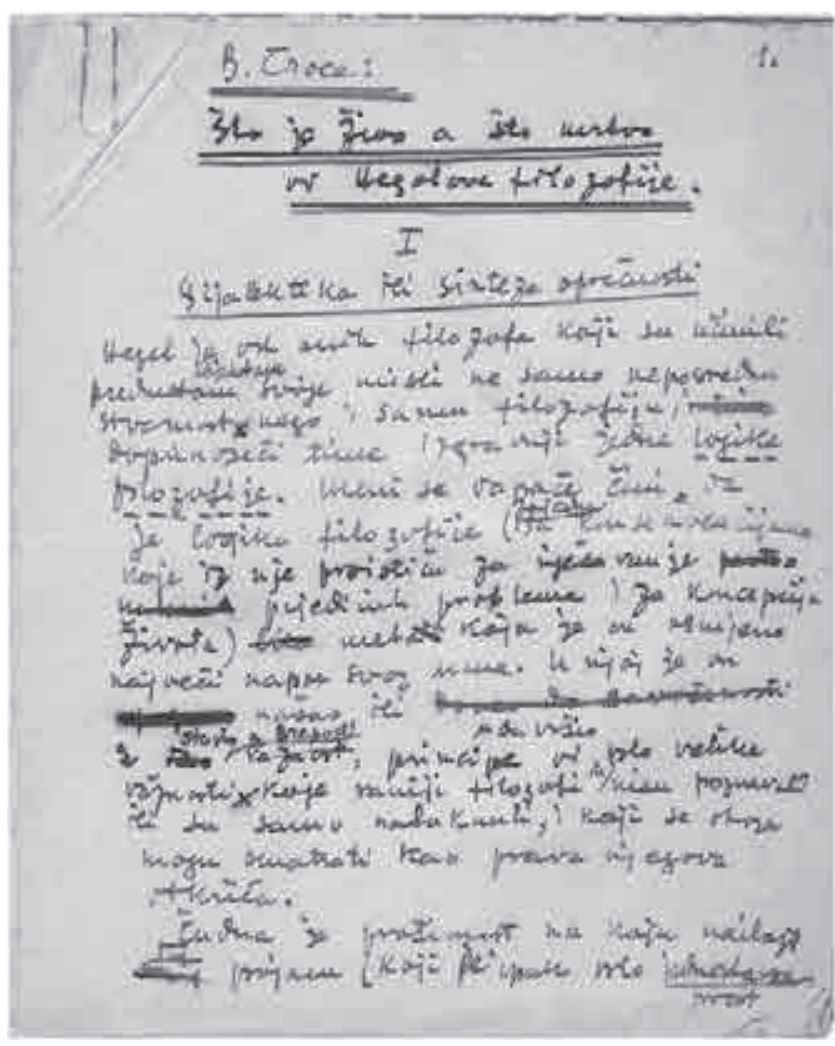

Sl. 2. Desničin neobjavljeni prijevod studije Benedetta Crocea „Što je živo a što mrtvo od Hegelove filozofije“ neoaristokratski stav tražiće umjetnost koja slavi borbu, pobjedu, osvajanje, dakle imperijalističku umjetnost. ${ }^{28}$

Usuđujem se pomisliti kako je zadnjenavedeni pasus jedan od onih što su Vladana Desnicu posebno naveli da se pozabavi Croceom, odnosno da se, prevodeći ga, pozove na njega u traženju odgovora na aktualno postavljane probleme. Znademo vrlo dobro da je u to vrijeme, koncem tridesetih godina, i u našim stranama sve više bila prisutna socijalna tendencioznost, sklonost krutoj funkcionalizaciji literature i jakim ideološkim shvaćanjima. Kad izlazi Desničina knjiga Croceovih eseja, 1938. godine, na djelu je upravo dramatičan „sukob na ljevici“ $s$ polariziranim stranama gotovo podjednako utilitarističkih opcija, socioloških simplifikacija i paraliterarnih akcija.

Eto, dok je Krleža vodio svoje bitke oko angažmana i prava na slobodu nedogmatskog izražavanja, Desnica je, posredstvom Crocea, branio autonomiju stvaralaštva i pravo pisca na vlastito viđenje. Daleko od militantne buke, mimo krležijanaca i antikrležijanaca, njegova je elitna pozicija „na duge pruge“ pokazala svoju učinkovitost i plodnost.

Nećemo se ovdje pozabaviti svim aspektima Desničina zanimanja za Crocea, pa ćemo samo spomenuti da je 1960. godine knjigom Croceovih eseja pod naslovom Književna kri- 
tika kao filozofija Desnica znatno dopunio i zaokružio svoj prevodilački saldo jer je četirima predratno objavljenim esejima dodao još dvadeset pet novoprevedenih tekstova. ${ }^{29} \mathrm{~A}$ smijemo spomenuti kako je i njegov prijevod korisne i glasovite knjige Od Giotta do Chagalla (izvorno Come si guarda un quadro) Lionella Venturija u neku ruku nastavak kročeanskih veza jer je i sam Venturi djelomično dužnik čitanja i prihvaćanja nekih Croceovih poticaja. ${ }^{30}$

Svjesni smo kako nismo uspjeli precizno detektirati splitske „kročeance“, odnosno kako smo tek naznačili neke osobnosti i fenomene bliske poznavanju i razumijevanju kročeanskih estetskih problema, ali pogled na razvedenu kulturnu klimu Splita između dva rata, kao značajnog releja za recepciju talijanske kulture u Hrvatskoj (i u južnoslavenskom prostoru) ostaje poticajan i otvoren daljnjim istraživanjima. Posebno bi pak vrijedilo razmotriti nužno dvosmislen odnos mnogih naših pisaca i kulturnih radnika prema Italiji u razdoblju fašizma, kao susjedu koji je privlačio nekim dometima i razinama kulturnog stvaralaštva, a istodobno plašio svojim imperijalističkim pretenzijama i iredentističkim presizanjima. Ali to je, ipak, sasvim poseban problem. U koji, srećom, Croce, kao uvjereni antifašist i liberal, ne ulazi.

\section{$\cos$}

\section{The “Croceans” of Split: A Look into the Culture of the City of Split between the Two World Wars}

In the 1920s and 1930s Split was home to many writers, painters and historians who were formed primarily in Italy, as well as many others who were familiar with the Italian language and cultural trends in Italy. They were for that reason almost vehicles for transferring Italian culture into the Croatian context. At the time of an intensive fascization of Italian society and culture, Benedetto Croce stood out as a thinker and cultural writer whose affirmation of the expressive character of art, the autonomy of art, and expressive liberalism and anti-fascism was very influential among the Split artists of bourgeois orientation, who were unattached to "social" movements (such as the "Krležians"). These made up the Split "Crocean" circle. Among them the one who merits most attention is Bogdan Radica, both as a literary critic and as Croce's interlocutor. Among the others who stand out are Albert Haler, Stipan Banović, Tin Ujević, Vinko Vitezica, then a number of young contributors to the Čiro Čičin Šain's Split-based journal Korablja, such as Ante Cettineo and Vladimir Rismondo as well as Vladan Desnica, who grew into a "Crocean" also for reasons of family tradition. Desnica translated and published a well-chosen selection of Croce's texts, Essays in Aesthetics, in Split in 1938. At that very time he decided to pursue a literary calling, and started writing some of his best works.

Key words: Benedetto Croce, Split, 1918-1941, Bogdan Radica, Vladimir Rismondo, Vladan Desnica

29 Benedetto Croce, Književna kritika kao flozofija (izbor i prevod Vladan Desnica), Beograd 1969.

30 Lionello Venturi, Od Giota do Chagalla (preveo Vladan Desnica), Zagreb 1952. 


\section{$\cos$}

\section{Literatura}

Stipan Banović, „Obaranje dvojice najvećih hrvatskih pjesnika“, Hrvatsko kolo, 1930., knj. 11, 205-245.

Benedetto Croce, Estetika kao nauka o izrazu i opća lingvistika, Zagreb 1960.

Benedetto Croce, Knjižeuna kritika kao filozofija, Beograd 1969.

Benedetto Croce, „Književnost kao 'izraz društva'“, Eseji iz estetike, Split 1938., 59.

Boško Desnica, „O jednom karakteru novije talijanske književnosti“, Srpski književni glasnik, 1912., knj. 29, br. 4, 291-300; br. 5, 371-376.

Vladan Desnica, Eseji iz estetike, Split 1938.

Albert Haler, Doživljaj ljepote, Zagreb 1943.

Benedeto KročE, Estetika kao nauka o izrazu i opšta lingvistika, Beograd 1935.

Bogdan Radica, „Nostalgije za redom“, Korablja, 1/1929., br. 1, 37-41.

Bogdan Radica, Agonija Evrope. Razgovori i susreti, Beograd 1940.

Bogdan Radica, „Albert Haler: 'Gundulićev Osman' - (S estetskog gledišta, Izd. Gece Kona. Beograd, 1929.)“, Korablja, 1/1929., br. 1, 49-51.

Bogdan Radica, „Anekdote o talijanskim piscima“, Nova Evropa, 1925., knj. 12, br. 9, $284-287$.

Bogdan RadicA, „Bilješke iz talijanske književnosti“, Hrvatska revija, 2/1929., br. 7, 445-448.

Bogdan RadicA, „Dva svedoka današnje Evrope“, Nova Evropa, 1936., knj. 29, br. 3, 91-96.

Bogdan RadicA, „Dvije historije B. Crocea“, Hrvatska revija, 2/1929., br. 7, 445-448.

Bogadan RadicA, Živjeti nedoživjeti, knj. 1: Uspomene hrvatskog intelektualca kroz moralnu i ideološku krizu Zapada, München - Barcelona 1982.

Kerubin ŠEgvić, „Je li Petar Preradović bio pjesnik“, Hrvatska revija, 5/1932., br. 1, 57-66.

Tin Ujević, „Atenski upečatak g. Bogdana Radice“, Jadranska pošta (Split), br. 186, 12. 8. 1930., 6-7.

Tin Ujević, „Experto Roberto (Prelistavajući Thomasa Manna)“, Jadranska pošta (Split), br. 129, 5. 7. 1930., 6-7; br. 130, 6. 7. 1930., 6-7; br. 131, 7. 7. 1930., 6-7.

Tin Ujević, „Poslije četiri stoljeća. Klišanin Patritius rođen 1529.“, Jadranska pošta (Split), br. 36, 13. 2. 1930., 2.

Tin Ujević, „Sumrak poezije“, Novo doba (Split), br. 312, 24. 12. 1929., 18-20.

Tin Ujević, „Tagor. Ovjenčani pjesnik Indije“, Jadranska pošta (Split), br. 106, 8. 5. 1930., 6-7.

Tin Ujević, „Trnokop u Silvijevoj bašti“, Pregled, 7/1933., knj. 9, sv. 119, 631 - 639.

Lionello Venturi, Od Giota do Chagalla, Zagreb 1952. 